\title{
Editorial
}

\section{Human genetic and reproductive technologies - an international medico-legal-religious impasse?}

\author{
Musa Mohd. Nordin*
}

\section{Introduction}

Heralded by the revelation of the double helical structure of the DNA molecule in 1953 , the $21^{\text {st }}$ century is aptly designated the biotechnology century. The $20^{\text {th }}$ century of physics, which saw the transformation of silicon into computing magic, was embraced with enthusiasm by virtually every household. However, unlike her predecessor, the same cannot be said about the advancements in biomedicine.

These revolutionary procedures in biotechnology have probed the outermost boundaries of what is scientifically possible and acceptable. Micro manipulation at the very earliest stages of human development, at the level of the embryo, single cell and genetic structure is undoubtedly a very delicate and sensitive issue with potentially explosive ethical, social, medico-legal and religious ramifications. Hence, the turbulent and not uncommonly hostile controversies that has since evolved.

Some of the issues in biotechnology which are debated contentiously and extensively across all segments of human society include assisted reproductive technologies, human reproductive cloning, therapeutic cloning, embryo research, genetic engineering, euthanasia, organ transplantation, abortion and contraception.

\section{The jurisprudence of biotechnology}

As a complete and comprehensive way of life, the teachings of Islam encompasses all fields of human endeavours, spiritual and material, individual and societal, economics and politics, national and international. This is well understood from the revelation during the occasion of the prophet's farewell pilgrimage.

"This day, I have perfected your religion for you, completed My favour upon you, and have chosen for you Islam as your religion" $(5: 3)$

And the instructions which regulate our everyday activity of life is called Shariah (Islamic law). The Shariah is the epitome of the Islamic spirit, the most typical manifestation of the Islamic way of life, the kernel of Islam itself ${ }^{1}$. Bioethical deliberations is inseparable from the religion itself, hence Islamic bioethics must remain and flourish within the confines of the Shariah.

All Muslim scholars and jurists are agreed that four sources of Islamic law remain in the forefront of all deliberations in Islamic jurisprudence (Fiqh), known as the Masadir al Shariah ${ }^{2}$. They are:

1. Quran

2. Sunnah (authentic traditions of the prophet)

3. Ijma' (consensus)

4. Qiyas (analogy)

Others which are not founded on a material source (nass) from the Quran or Sunnah but capturing the spirit of the Shariah and taking into consideration the welfare of the community include:

1. Istihsan - the choice of one of several lawful options

2. Istishab - continuation of an existing ruling until the contrary is proved

3. Urf - customs or precedent which does not contradict nass

*Corresponds to: Dr. Musa Mohd. Nordin, MBBCH (Wales), FRCP (Edin); FAMM Consultant Paediatrician \& Neonatologist, Damansara Specialist Hospital, Kualalumpur, Malaysia. Email: musamn@gmail.com. 
4. Maslahah or Istislah - consideration of public interest or welfare

5. Shar'u man qabluna - the laws of our predecessors, either confirmed or abrogated by the primary sources

6. Qawl as-sahabi - the narrative of the companion of the prophet

The purposes of the law (Maqasid al Shariah) arranged in their order of importance are directed towards the preservation of ${ }^{3}$ :

1. Deen (religion)

2. Nafs (life)

3. Aql (mind)

4. Nasl (progeny)

5. Maal (property)

This classification which is permanent and immutable defines succinctly and clearly the objectives of the community and gives it balance and a sense of purpose. Three of these priorities are directly related to the preservation of health, namely life, mind and progeny.

And from the outset it must be emphasized that the Shariah is guided by five cardinal principles (Qawaid al Shariah). These are ${ }^{4}$ :

1. The principle of intention - intent is all important in actions

2. The principle of certainty - certainty cannot be changed by doubt and all acts are permissible unless there are clear prohibitions

3. The principle of injury - do no harm, injury must be removed or compensated

4. The principle of hardship - hardship calls forth ease and facilitation, need or necessity makes for allowing what is prohibited

5. The principle of custom - custom or precedent is the rule unless contradicted by nass

These cardinal rules lead the scholars and jurists to think of Islamic Fiqh as the subject of five vital conceptions ${ }^{5}$ :
1. There are few absolute obligations (takalif)

2. Gradualism in the promulgation of laws

3. Making the burden lighter when making and executing laws

4. Hardship is avoided and necessity is taken into account

5. Justice and equity must always prevail

The Shariah is therefore a living, dynamic and relevant entity. It is for everyone, everywhere and for all times. It also describes itself as a guide, a light and a mercy $^{6}$. It is this philosophy of the law which is alive to the contemporary challenges of advancing biotechnologies. I have chosen to illustrate this harmony and the relevance of the law to three areas of cutting edge biotechnology, namely:

1. Reproductive human cloning

2. Therapeutic cloning

3. Genetic technology and human embryo research

\section{Human reproductive cloning}

When man was experimenting with cloning in plants, frogs and small marine animals, the Islamic Organisation of Medical Sciences (IOMS) based in Kuwait, convened a seminar in 1983 in which 2 papers were presented which dealt with the potential of human cloning and the shariah perspective on this possibility. When the cloning of Dolly the sheep by the technique of somatic cell nuclear transfer was announced in February 1997, the IOMS in their $9^{\text {th }}$ Fiqh Medical seminar updated their juristic opinion on this most contentious issue ${ }^{7}$.

Like the IOMS, virtually every Islamic seminar, jurisprudence council or individual scholars have concluded that cloning procedures aimed at producing human clones is not permissible. The majority considered it Haram (not permissible) in all its details ${ }^{8}$. Whilst a minority opinion considered in Haram as a way to prevent a cause of harm (the 
necessity to refrain from causing harm to oneself and others). This latter juristic opinion keeps open the option of readdressing the issue should new information become available and approved by Shariah. The use of somatic cell nuclear transfer technology even between husband and wife was also not approved.
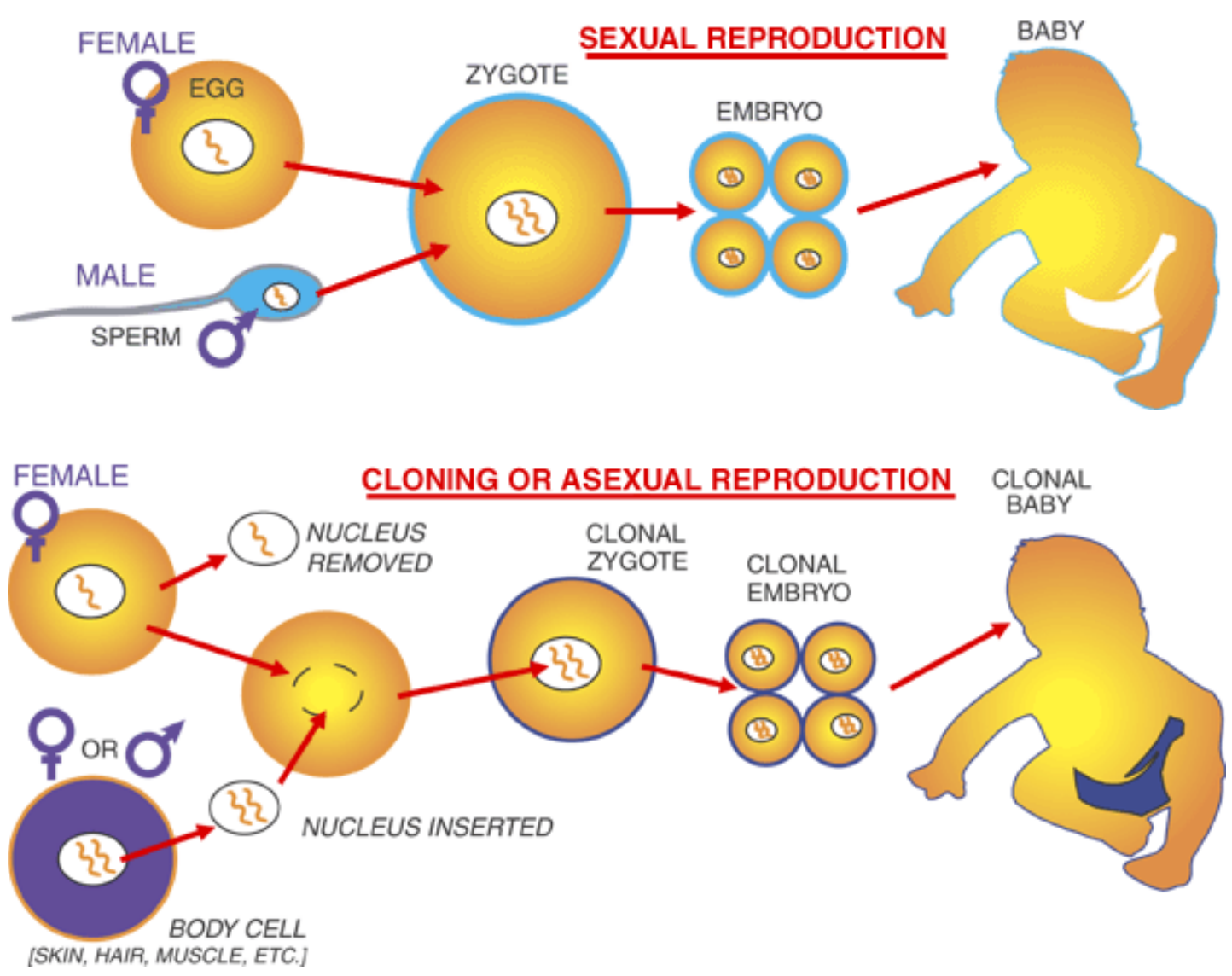

The rationales for prohibition were as follows:

a. The basic concept in reproduction is to abide by the Shariah approved system of legally binding marriage, through the union of the sperm and ovum.

b. Human cloning is against the natural process (Fitrah) of human relationship of marriage and reproduction

c. The major harms far exceed the benefits. These include the disruption of lineage, family relationships and social fabric of humanity.

d. The anticipated social, moral, psychological and legal implications of human copies. e. The possibility of interfering with the male-female population dynamics

The ethics aside, the science of human reproductive cloning is not evidence based:

1. It is an inexact science - there were 277 attempts before Dolly was possible. "Even with mammals the risks are monumental let alone humans, it is criminally irresponsible" says Ian Wilmut, the "creator of Dolly". Failure rates are in excess of $98 \%$

2. It is an inefficient technology - Abortion rates are $10 \mathrm{x}$ higher, stillbirth rates are $3 x$ higher. Natural reproduction is more efficient and ... more fun. 
3. Unproven safety - Dolly suffered from premature rheumatism and early death (she was "a sheep in lamb's clothings"). Other abnormalities include large offspring syndrome, underdeveloped lungs, reduced immunity, and increased congenital anomalies. The list of misadventures increase by the day and which infertility expert or cloner is going to publish their failures!

4. Besides it compromises the gene pool it reduces genetic variability and diversity. One virulent pathogen may be sufficient to wipe out the whole clone population.

The national and international responses to the new technologies of human reproductive cloning have suffered a policy lull. Eight years post-Dolly, only a few countries have either drafted or enacted laws to bring human genetic and reproductive technology under responsible societal governance. As of November $2003,77 \%$ of countries have not taken action to ban reproductive human cloning. Malaysia is in the final stages of drafting laws to ban the reproductive cloning of human beings.

Apart from a small minority of "rogue cloners" there is an international consensus against the reproductive cloning of human beings. However the opportunity to elaborate an international convention to ban reproductive human cloning was lost when member countries disagreed on the extent of the ban.

The USA and Costa Rica in the Policy on UN Cloning Treaty 2003, proposed a full ban on both reproductive and therapeutic cloning; whilst other member countries supported the Belgium proposal for a partial ban that is to ban reproductive cloning and allow national discretion on therapeutic cloning.

\section{Therapeutic cloning}

Unfortunately, the confusion and disgust at the prospect of cloning and creating babies has been transferred to therapeutic cloning. In therapeutic cloning unlike human reproductive cloning the end point is not cloning a human being. This technology involves the production of human clonal embryos for the purpose of harvesting stem-cells, tissues and organs. This would open the potential of curing a whole host of chronic and debilitating diseases including diabetes mellitus, Parkinsonism, myocardial infarction and spinal injuries.

The source of the totipotent stem cells has however been a source of intense controversy. Stem cells found in umbilical cord blood, bone marrow and aborted fetuses are generally acceptable from the ethical and moral point of view. Though less plastic, scarce and sometimes quite inaccessible, there have been some success stories with the use of these non-embryonic stem cells.

The use of embryonic stem cells (ESC) is however fraught with highly charged religio-bio-ethical debate. The source of controversy revolves around the various questions about when life becomes a human life; namely:

1. Is an ovum and sperm a person?

2. When do the products of conception become a person?

3. Does a zygote have a full set of human rights?

4. Does the foetus have a soul?

This concept of personhood is neither logical nor empirical. It is based on one's fundamental assumptions about the nature of the world. It is primarily a religious or quasi-religious concept.

The Roman Catholics believe that the soul enters the body at conception and the fertilized ovum is a human person will full human rights. Pope John Paul II, on 29 August 2000 said, "Methods that fail to respect the dignity and value of the person 
must always be avoided. I am thinking in particular of attempts at human cloning with a view to obtaining organs for transplants: these techniques, in so far as they involve the manipulation and destruction of human embryos, are not morally acceptable, even when their proposed goal is good in itself'

The scientific paradigm defines the preembryonic stage as the period from fertilization up to the determinant of the primitive streak at the age of 14 days. The pre-embryo is unable to feel pain or pleasure and therefore has no moral status. They may be cryopreserved, discarded or used for research purposes.

Lord May of Oxford, the President of the Royal Society said, "to cut off this research (without clear understanding of the science of therapeutic cloning and its potential to contribute to mankind) would be an act of intellectual vandalism comparable to papal censorship of Galileo and Copernicus."

The first verse revealed to Prophet Muhammad in the cave of Hira' translates as follows:

"Read! In the name of your Lord, who has created. Has created man from alaqa." (96:1-2)

This verse embodies two very significant messages. From the outset, the Quran emphasizes the primacy of knowledge and follows this with the first lesson in embryology, the very creation of man himself.

The Quran is a book of guidance to invite mankind to the truth and salvation. But nonetheless it contains many "signs" which invites mankind to reflect upon his creation and the world that surrounds him. In various verses, it illustrates lucidly both the physical and spiritual dimensions of man's creation. In chapter 23, verses 12-14, the Quran says:
"And indeed We created man from a quintessence of clay. Then we placed him as a small quantity of liquid (nutfa) in a safe lodging firmly established. Then we have fashioned the nutfa into something which hangs (alaqa). Then We made alaqa into a chewed lump of flesh (mudgha). And We made the mudgha into bones, and clothed the bones with flesh. And then We brought it forth as another creation. So blessed be God, the best to create"

The nutfa represents the blastocyst which embeds within the endometrium. The alaqa, much intrigued the distinguished embryologist, Prof. Moore who was puzzled at how 1400 years ago anyone could accurately describe it as something which clings to the inner uterine wall like a leech. The scholars of Quran were similarly unable to explain the concept of mudgha until microsopy revealed that the chewed lump of flesh resembled accurately the appearances of the somites. And note how explicit the verses have been in illustrating that the ossification centres preceded the formation of the myotomes.

In another verse the Quran very clearly revealed another phase of man's being, the process of ensoulment.

"And breathe into him of His spirit" (32:9)

The soul is a metaphysical concept which is fundamental in Islam and it defines a human individual. The majority opinion in Islam accepts the 120th day of pregnancy as the time of ensoulment. Eventhough ensoulment occurs later; the embryo is respected from the onset of fertilization and acquires consideration as a human foetus after implantation.

And based on these fundamental premises, at least three Islamic Fiqh (Jurisprudence) Councils have given permission for the use of surplus embryos from IVF laboratories for ESC research ${ }^{9,10,11}$. However, it is not permissible at this juncture, to consciously 
generate pre-embryos either by conventional IVF techniques or somatic cell nuclear transfer (SCNT) for ESC research.

As at November 2003, $6(3 \%)$ countries have allowed therapeutic cloning whilst 30 $(16 \%)$ have prohibited it. The 6 countries in favour of allowing therapeutic cloning to proceed within stipulated policy guidelines are China, Singapore, Belgium, UK, Cuba and USA.

The Federal Embryo Protection Law (1990) of Germany prohibits both reproductive and therapeutic cloning. This represents the spectrum of countries with "relatively restrictive" laws related to reproductive technologies. Others include Austria, the Scandinavian countries, Ireland, Italy, Netherlands, Spain and Switzerland.

The other end of the spectrum is represented by the United Kingdom's Human Fertilisation and Embryology Act (1990) and Human Reproductive Cloning Act (2001) and Singapore's Bioethics
Advisory Committee (BAC) Report on "Ethical, Legal and Social Issues in Human Stem Cell Research, Reproductive and Therapeutic Cloning" which was approved by the government on 18 July 2002. The UK and Singapore "more permissive" regulations allows the generation of embryos by both IVF and SCNT technologies if there is a demonstrable and exceptional need which cannot be met by the use of surplus embryos.

The "in-between" policies are demonstrated by the Canadian's new Assisted Human Reproduction Act (2004) and Australia's Research Involving Embryos Act (2003). They both allow the utilization of surplus IVF embryos for research but prohibit the creation of human embryos for research and SCNT for research and reproduction. The current thinking in our Malaysian National Committee on Human Cloning seems to favour this line of thought and legal framework; which is also resonates well with the fatwa issued by the three jurisprudence councils in Jeddah, USA and Jordan.

\begin{tabular}{|c|c|c|c|c|c|c|c|c|c|}
\hline \multirow[t]{3}{*}{ Region } & \multirow{3}{*}{$\begin{array}{c}\text { Countries } \\
\#\end{array}$} & \multirow{2}{*}{\multicolumn{2}{|c|}{\begin{tabular}{|c|}
$\begin{array}{c}\text { Reproductive } \\
\text { Cloning }\end{array}$ \\
Prohibited \\
\end{tabular}}} & \multicolumn{4}{|c|}{ Research Cloning } & \multirow{2}{*}{\multicolumn{2}{|c|}{$\begin{array}{c}\text { IGM } \\
\text { Prohibited }\end{array}$}} \\
\hline & & & & \multicolumn{2}{|c|}{ Prohibited } & \multicolumn{2}{|c|}{ Allowed } & & \\
\hline & & $\#$ & $\%$ & $\#$ & $\%$ & $\#$ & $\%$ & $\#$ & $\%$ \\
\hline Africa & 53 & 1 & $2 \%$ & 1 & $2 \%$ & 0 & $0 \%$ & 1 & $2 \%$ \\
\hline Middle East & 23 & 1 & $4 \%$ & 0 & $0 \%$ & 0 & $0 \%$ & 1 & $4 \%$ \\
\hline $\begin{array}{l}\text { South Asia / East } \\
\text { Asia / Pacific }\end{array}$ & 33 & 6 & $18 \%$ & 3 & $9 \%$ & 2 & $6 \%$ & 5 & $15 \%$ \\
\hline Europe - Eastern & 24 & 14 & $58 \%$ & 8 & $33 \%$ & 0 & $0 \%$ & 9 & $38 \%$ \\
\hline Europe - Western & 24 & 16 & $67 \%$ & 13 & $54 \%$ & 2 & $8 \%$ & 8 & $33 \%$ \\
\hline $\begin{array}{l}\text { Americas \& } \\
\text { Caribbean }\end{array}$ & 35 & 8 & $23 \%$ & 5 & $14 \%$ & 2 & $6 \%$ & 3 & $9 \%$ \\
\hline World & 192 & 46 & $23 \%$ & 30 & $16 \%$ & 6 & $3 \%$ & 27 & $14 \%$ \\
\hline
\end{tabular}

Except for Israel, none of the nations in the Middle East have taken legal action to regulate either reproductive or therapeutic cloning. As at 6 November 2003, Bahrain, Iran, Jordan, Kuwait, Lebanon, Oman, Pakistan, Qatar, Saudi Arabia, Syria, UAE and Yemen voted in favour of Iran's motion on the UN Cloning Treaty Process, to postpone further discussions for another 2 years. This is illustrated in the table above. 
Previously it was thought that it would be extremely difficult to develop comprehensive policies to govern human genetic and reproductive technologies. Despite the earlier skepticism, various countries have now shown that it is possible to break the policy deadlock and draft legislation to regulate these new technologies of human genetic modification. Despite their different political and social experiences, some of the national policies thus available have exhibited a remarkable sharing of core principles; namely:

a. they affirm technologies with a real chance of preventing or curing disease

b. they ban technologies which could harm children or open the door to free market eugenics

c. they ensure research involving embryos is tightly regulated

d. they establish publicly accountable means to review policies \& make new ones

e. they pose no risk for reproductive rights

Probably one of the most far reaching thoughts on this highly controversial issue of ESC research has been that propounded by Sheikh Dr. Yusuf Al-Qardawi, a highly respected and contemporary Muslim scholar who related in his concluding remarks after a lengthy juristic deliberation the following position ${ }^{12}$ :

"If it becomes possible through research to clone organs such as the heart, liver, kidneys or others which may benefit those who are in dire need of them; then this is permitted by religion and the researcher or scientist will receive the reward from Allah. This is because the research will confer benefit on humanity without loss to others or infringing upon them. Therapeutic cloning with this noble research pursuit is permissible and it is encouraged. In fact, in some circumstances, it may become mandatory to enhance this research in accordance with the need and man's research capability and accountability."

The following diagram illustrates the extreme potential for therapeutic cloning, with virtually zero risk of graft versus host disease (GVHD), with the option of either de-differentiation of the patients' indigenous stem cells or utilizing somatic cell nuclear transfer technology to generate embryonic stem cells.

\section{Genetic technology and human embryo research}

Two hadiths (authentic traditions) related from the Prophet has helped us to have a better insight into the science of genetics.

"Select your spouses carefully in the interest of your offspring because lineage is a crucial issue"

"Do not marry your close relatives because you will beget weak offsrpings"

The second Caliph of Islam, Omar ibn ElKhattab, upon noting that a particular tribe intermarried with increased frequency, remarked to them:

"You have weakened your descendants. You should marry strangers (people outside your tribe)".

The spirit of the exhortations of the Prophet SAW and his companion was to secure normal and healthy babies, protection of their early well being, endowed with the benefits of good genes from both parents and the prevention of congenital malformations and its consequent disabilities.

A variety of inherited diseases may now be diagnosed in the pre-embryo stage prior to implantation into the uterus. Highly sensitive polymerase chain reaction (PCR) techniques have enabled the rapid amplification of minute amounts of DNA material from the embryonic cells. 
Fluorescent in situ hybridization (FISH) technologies with combination the genetic analysis of embryonal sex and chromosomal probes have made possible various aneuploidies $^{13}$.

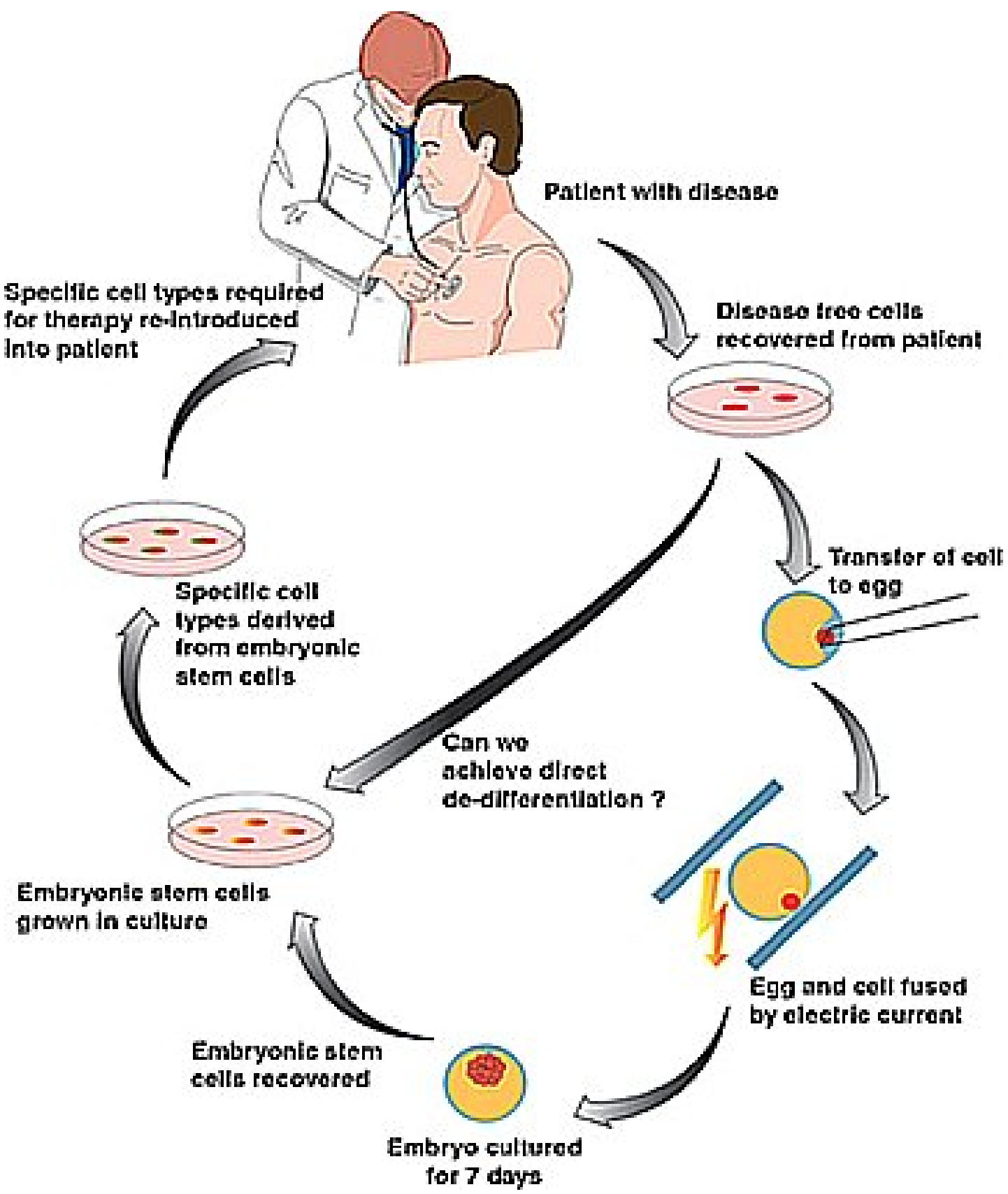

Some of the potentially debilitating diseases which may be screened include Trisomy 13, 17 and 21, cystic fibrosis, haemophilia, Marfan's syndrome, incontinentia pigmentosa, $\mathrm{x}$-linked immune deficiency, retinitis pigmentosa, fragile $X$ syndrome, muscular dystrophy and LeschNyhan disease. The first preimplantation genetic diagnosis (PGD) was achieved in 1989. Since then, well over 200 diseases or conditions has been further isolated with ongoing PGD research ${ }^{14}$.

The First International Conference on Bioethics in the Muslim World held in Cairo from 10-13 Dec 1991 examined very 
carefully this area of pre-embryo research $^{15}$. Collaborating this with the decisions of other scientific cum Islamic jurisprudence seminars, the following practice guidelines may be summarized:

1. Cryopreserved pre-embryos may be used for research purposes with the free and informed consent of the couple.

2. Research conducted on pre-embryos is limited only to therapeutic research. Genetic analysis of pre-embryos to detect specific genetic disorders is permissible. Hence diagnostic aids should be provided for couples at high risk for selected inherited diseases. The treated embryo may only be implanted into the uterus of the wife who is the owner of the ova and only during the span of the marriage contract.

3. Any pre-embryos found to be genetically defective maybe rejected from transfer into the uterus after proper counselling by the physician.

4. Research aimed at changing the inherited characteristics of pre-embryos (e.g. hair and eye colour, intelligence, height) including sex selection is forbidden.

5. Sex selection is however permitted if a particular sex predisposes to a serious genetic condition. One of the first couple to use the technique of sex selection was hoping to escape a neurologically debilitating disease known as x-linked hydrocephalus, which almost always affected boys. Embryonal sex selection would make possible the weeding out of other serious $\mathrm{x}$-linked disorders including haemophilia, Duchenne muscular dystrophy and fragile $\mathrm{X}$ syndrome.

6. The free informed consent of the couple should be obtained prior to conducting any non-therapeutic research on the preembryos. These pre-embryos should not be implanted into the uterus of the wife or that of any other woman.

7. Research of a commercial nature or not related to the health of the mother or child is not allowed.
8. The research should be undertaken in accredited and reputable research facilities. The medical justification for the research proposal must be sound and scientific and conducted by a skilled and responsible researcher.

The designer baby technology or inheritable genetic modification (IGM) has further accentuated the ethical debate often referred to as "slippery slope" issues. The world's first true designer baby, Nash Brown, was born on 29 August 2000. He was conceived specifically for the sake of his six year old sister, Molly who suffered from Fanconi's Anaemia. His umbilical cord blood was transfused into Molly, with the hope of curing her condition.

Another landmark case was in the UK in 2001, where a British couple was given the go ahead by the courts to select an IVF baby who is Thalassaemia free and has a tissue make-up which precisely match their son Zain who suffers from Thalassaemia and does not have a compatible donor. Umbilical cord blood from the IVF baby would be transplanted into Zain to cure his Thalassaemia.

The table shows that only 27 (14\%) countries have taken action to ban the creation of designer babies.

\section{Conclusion}

Islamic medical bioethics is firmly grounded on the fundamental tenets of the Islamic Shariah. The close collaboration between the scholars of jurisprudence and the scientific and medical fraternity has enabled her to keep abreast of the plethora of advancing biotechnologies.

Despite the wide ranging bio-religioethical problems and dilemmas posed by these emerging biotechnologies, Islamic medical bioethics, has provided a "middle of the road" approach moderating between the extremes of conservatism and liberalism. This it does without impeding 
the genuine and responsible quest for new knowledge and breakthroughs in new research frontiers.

It has provided a legal framework for responsible societal governance of human genetic and reproductive technologies and banned all forms of free market eugenics.
Allah says in Chapter 2, verse 143:

"Thus we have appointed you a middle nation, that you may be witness against mankind, and that the messenger maybe witness against you ..."

\section{References}

1. Schacht, Joseph. An introduction to Islamic Law. Reprinted 1966, 1971:1.

2. Ash-Shafi'I; al-Umm, 1993, vol. 7:492-494; Ramadan, Islamic Law, 1970:33; Madkour, alMadkhal, 1966:90,196.

3. Ash-Shatibi, al-Muwafaqat, 1975, vol. 2:10.

4. Borno, al-Wajiz, 1998, pp8,63.

5. Madkour, al-Madkhal, 1966:12-20.

6. Al-Quran 5:44-46.

7. Recommendations of the $9^{\text {th }}$ Fiqh-Medical Seminar; Islamic Organisation of Medical Sciences.

8. Aly A. Mishal. Cloning and advances in molecular biotechnology. FIMA Year Book 2002, pp 38.

9. The Council of Islamic Fiqh Academy of the Muslim World League. 2003; $17^{\text {th }}$ session in Makkah, 13-17 December.
10. Fiqh Council of North America, International Institute of Islamic Thought, Graduate School of Islamic and Social Sciences, Islamic Institute news release August 27, 2001.

11. Aly A. Mishal. Stem cells: Controversies and ethical issues. Jordan Medical Journal. May 2001; 35(1) pp 80-82.

12. Yusuf Al-Qardawi. Hadyul Islam Fatawi Mu'athirah. Darul Qalam Kuwait 2001. Translated Gema Insani Press, October 2002.

13. Grifo JA,et al. Update in preimplantation diagnosis. Advances and problems. Current Opinions Obstet Gynae 8:135-138.

14. Fact Sheet: Preimplantation Genetic Diagnosis. American Society for Reproductive Medicine. Dec 1996.

15. Serour GI. Proceeding to the $1^{\text {st }}$ international congress on bioethics in human reproduction research in the Muslim world. IICPSR 1992 Vol II. 